Pengaruh Pemberian Folat Dosis Bertingkat terhadap Tingkat Kerusakan Retina

Mencit yang Diberi Metanol 50\% Peroral

\title{
The Effect Of Folic On Different Dosage Level Against Retina Destruction Level Of Mice With Peroral Methanol 50\%
}

\author{
I Gusti Ngurah Agung Darma Putra ${ }^{1}$, Al Munawir ${ }^{2}$, Sugiyanta ${ }^{3}$ \\ ${ }^{1}$ Mahasiswa Fakultas Kedokteran Universitas Jember \\ ${ }^{2}$ Laboratorium Patologi Anatomi Fakultas Kedokteran Universitas Jember \\ ${ }^{3}$ Laboratorium Biokimia Fakultas Kedokteran Universitas Jember \\ Jalan Kalimantan No. 37 Kampus Tegalboto, Jember 68121 \\ e-mail korespondensi: diahtamankampus@yahoo.com
}

\begin{abstract}
Abstrak
Terjadi berbagai kasus keracunan metanol beberapa tahun terakhir. Keracunan metanol menyebabkan kebutaan, gangguan CNS, dan asidosis metabolik. Salah satu pengobatan pada keracunan metanol adalah menggunakan asam folat. Asam folat memiliki peran penting pada metabolisme metanol dalam tubuh. Penelitian ini bertujuan untuk mengetahui pengaruh pemberian folat terhadap tingkat kerusakan retina pada keracunan metanol. Metode yang digunakan eksperimental laboratoris (True Experimental Design) dengan post test only control group design. Penelitian ini dilakukan dengan lima kali pengulangan pada setiap perlakuan. Sampel yang digunakan adalah mencit dengan umur 2-3 bulan dan berat 25-30 gram. Perlakuan pada penelitian ini dibedakan menjadi 5 kelompok yaitu kelompok kontrol hanya diberi pelet dan aquades, kelompok kontrol negatif diberikan metanol $7 \mathrm{~g} / \mathrm{kgBB}$, kelompok perlakuan 1, 2, dan 3 diberikan metanol $7 \mathrm{~g} / \mathrm{kgBB}$ serta folat dengan dosis $1 \mathrm{mg} / \mathrm{kgBB}, 3 \mathrm{mg} / \mathrm{kgBB}$ dan $5 \mathrm{mg} / \mathrm{kgBB}$ secara berurutan. Lama perlakuan dilakukan selama 24 jam, kemudian dilakuan pengambilan organ mata dan dilakukan pembuatan preparat. Kerusakan retina dinilai dengan skor yang telah ada pada setiap penilaiannya. Berdasarkan hasil penelitian dapat disimpulkan bahwa pemberian asam folat dapat menurunkan tingkat kerusakan retina pada keracunan metanol.
\end{abstract}

Kata Kunci: Asam folat, metanol, mencit, dan retina.

\begin{abstract}
In recent years, there are many methanol poisoned cases. Methanol poisoned cause of blindness, CNS problem, and metabolic acidosis. Folic acid is the one of many medicinal treatment for methanol poisoned. Folic acid has important role on methanol metabolism in our body. The aim of the study was to known the effect of addition folic acid on retina damage level of methanol poisoned. The method is experimental laboratories (true experiment design) with post test only control group design. The study included 5 separate test. The subject were mice which in 2 - 3 months age and had weight about 25 - 35 gr. There were 5 groups subject in the study. There were control group which given usual meals for mice and aquadest, negative control group which given methanol $7 \mathrm{gr} / \mathrm{kgBW}$, treatment group 1,2, and 3 were given methanol $7 \mathrm{gr} / \mathrm{kgBW}$ and folic acid $1 \mathrm{mg} / \mathrm{kg} \mathrm{BW}, 3 \mathrm{mg} / \mathrm{kgBW}$, and $5 \mathrm{mg} / \mathrm{kgBW}$. The treatment was given about 24 hours, then the eyes of the mice were taken to made blood smear. Damage of eyes were evaluated based score determined before. It can be concluded that addition folic acid can reduce retina damage level of metanol poisoned.
\end{abstract}

Keywords: Folic acid, methanol, mice, and retina 


\section{Pendahuluan}

Kasus keracunan metanol semakin meningkat seiring dengan ditetapkannya Peraturan Menteri Keuangan mengenai pajak untuk minuman yang mengandung alkohol (Mulyani, 2010). Ketidakseimbangan harga dan daya beli konsumen mengakibatkan produsen membuat alkohol dengan mencampurkan beberapa bahan. Metanol merupakan salah satu bahan campuran yang digunakan.

Metanol pada dasarnya tidak berbahaya bagi tubuh, namun hasil metabolisme metanol dalam tubuh berupa asam format dapat mengakibatkan keracunan metanol (Pritchard, 2007). Asam format yang terakumulasi lama dalam tubuh dapat mengakibatkan rabun, kebutaan, gangguan CNS dan asidosis metabolik (Seme et al, 1999).

Penanganan pada keracunan metanol masih bersifat supportif (Acute Exposure Guidelines Levels, 2005). Hemodialisis dapat dilakukan untuk mengurangi kadar asam format dalam darah. Pemberian antidotum seperti etanol dan fomepizole dapat diberikan untuk mengurangi akumulasi asam format dalam darah. Asam folat dapat diberikan untuk mempercepat metabolisme metanol. Pemberian terapi tambahan juga dapat diberikan seperti sodium bikarbonat untuk asidosis metabolik dan diazepam untuk mengurangi kejang (Seme et al, 1999).

Asam folat dapat mempercepat metabolisme asam format menjadi karbondioksida dan air, sehingga akumulasi asam format dalam tubuh semakin berkurang. Semakin cepat pengeluaran asam format maka efek kerusakan dalam tubuh semakin berkurang (Seme et al, 1999).

\section{Metode Penelitian}

Penelitian ini menggunakan metode penelitian eksperimental laboratoris (True Experimental Design) dengan post test only control group design. Desain penelitian ini dipilih karena tidak dilakukan pretest terhadap sampel sebelum perlakuan. Pada penelitain ini dilakukan randomisasi baik pada kelompok kontrol maupun kelompok eksperimen. Kelompok-kelompok tersebut dianggap sama sebelum dilakukan perlakuan. Selanjutnya dilakukan pengukuran pengaruh perlakuan (intervensi) pada kelompok eksperimen dengan cara membandingkan dengan kelompok kontrol.

Penelitian ini mengambil 2 tempat sebagai lokasi pelaksanaan, yaitu : Laboratorium Faal Fakultas Kedokteran Gigi Universitas Jember sebagai tempat perlakuan pada masing-masing kelompok dan Laboratorium Histo-Patologi Anatomi Fakultas Kedokteran Universitas Jember sebagai tempat pemeriksaan preparat mata. Populasi penelitian ini adalah mencit dengan umur 2-3 bulan dan berat 25-30 gram.

Alat-alat yang diperlukan diantaranya adalah kandang hewan coba berukuran $40 \mathrm{x}$ $30 \times 20 \mathrm{~cm}$, botol minum hewan coba, wadah makanan, kawat kasas penutup, sekam, sonde lambung, papan fiksasi, jarum pentul, pinset, scapel, gelas ukur dan timbangan analitik. Bahan-bahan yang dipersiapkan adalah metanol 100\%, asam folat, $\mathrm{CMC} \mathrm{Na}$, aquades dan formalin.

Pembuatan larutan metanol 50\% dilakukan dengan cara mencampurkan metanol $100 \%$ dan aquades dengan perbandingan 1:1. Untuk mempermudah pemberian asam folat dilakukan suspensi asam folat dari bentuk tablet ke dalam bentuk cair. Sebanyak $20 \mathrm{mg}$ asam folat tablet digerus hingga membentuk serbuk. Karena serbuk asam folat tidak larut dalam air maka suspensi dilakukan dengan menggunakan CMC Na 1\%. Sebanyak 0,4 gram CMC Na dilarutkan dalam $40 \mathrm{ml}$ air hangat sehingga membentuk larutan CMC Na 1\%. 20 mg serbuk asam folat kemudian di campur dengan $40 \mathrm{ml}$ larutan CMC Na 1\% sehingga terbentuk suspensi asam folat dengan perbandingan $1 \mathrm{mg}$ asam folat dalam $2 \mathrm{ml}$ CMC Na $1 \%$.

Penelitian ini dilakukan dengan lima kali pengulangan pada setiap perlakuannya. Kelompok perlakuan dalam penelitian ini dibagi menjadi 5 yaitu kelompok kontrol yang hanya diberi pelet dan aquades, kelompok kontrol negatif yang diberi metanol $7 \mathrm{~g} / \mathrm{kgBB}$, kelompok perlakuan I diberi metanol $7 \mathrm{~g} / \mathrm{kgBB}$ dan asam folat 1 
$\mathrm{mg} / \mathrm{kgBB}$, kelompok perlakuan II diberi metanol $7 \mathrm{~g} / \mathrm{kgBB}$ dan asam folat 3 $\mathrm{mg} / \mathrm{kgBB}$, serta kelompok perlakuan III diberi metanol $7 \mathrm{~g} / \mathrm{kgBB}$ dan asam folat 5 $\mathrm{mg} / \mathrm{kgBB}$. Pemberian asam folat pada kelompok perlakuan I, II dan III dilakukan 12 jam sebelum pemberian menanol. Pemberian jeda waktu dilakukan untuk mengurangi terjadinya kesalahan pada penyerapan asam asam folat. Pada penelitan sebelumnya didapatkan bahwa pemberian metanol $50 \%$ peroral dapat mengakibatkan terjadinya kerusakan pada sel gaster (Fadillal, 2010).

Lama perlakuan dilakukan selama 24 jam. Setelah 24 jam, dilakukan pengambila organ mata dan dilakukan fiksasi dalam formalin 10\% minimal 24 jam. Pembuatan preparat dilakukan dengan pengecatan hematoksilin eosin (HE). Penilaian kerusakan retina diambil dari penilaian histopatologi yang dirumuskan oleh El-Bakary et al (El Bakary et al, 2006). Analisis data dilakukan menggunakan uji one way Anova yang sebelumnya telah dilakukan uji normalitas dengan Kolmogorov-Smirnov dan uji normalitas menggunakan uji Levene. Untuk mengetahui perbedaan bermakna pada setiap kelompok dilakukan uji Post Hoc sebagai uji lanjutan.

\section{Hasil Penelitian}

Rata-rata hasil yang diperoleh pada setiap kelompok perlakuan menunjuk hasil yang signifikan terhadap tingkat kerusakan retina. Pada perlakuan I dengan pemberian asam folat dosis $1 \mathrm{mg} / \mathrm{kgBB}$ menunjukkan rata-rata nilai histopatologi kerusakan retina sebesar 11,2 dalam 5 kali pengulangan., dengan standar deviasi sebesar 1,09. Pada perlakuan II dengan pemberian asam folat dosis $3 \mathrm{mg} / \mathrm{kgBB}$ menunjukkan rata-rata nilai histopatologi kerusakan retina sebesar 14 dalam 5 kali pengulangan., dengan standar deviasi 0,7. Pada perlakuan III dengan pemberian asam folat dosis $5 \mathrm{mg} / \mathrm{kgBB}$ menunjukkan ratarata nilai histopatologi kerusakan retina sebesar 15.8 dalam 5 kali pengulangan., dengan standar deviasi 2,05.

Untuk kelompok kontrol tanpa pemberian metanol dan asam folat didapatkan nilai rata-rata sebesar 20 dalam 5 kali pengulangan, dengan standar deviasi 0 . Pada kontrol negatif yang hanya diberi metanol $7 \mathrm{~g} / \mathrm{kgBB}$ didapatkan rata-rata nilai histopatologi kerusakan retina sebesar 5.4 dalam 5 kali pengulangan, dengan standar deviasi 1,67.

Tabel 1. Nilai histopatologi kerusakan retina

\begin{tabular}{ll}
\hline Kelompok & $\begin{array}{l}\text { Kerusakan retina (Rerata } \\
\text { Std. Deviasi) }\end{array}$ \\
\hline K- & $5,4 \pm 1,67$ \\
K+ & $20 \pm 0,00$ \\
P1 & $11,2 \pm 1,09$ \\
P2 & $14 \pm 0,7$ \\
P3 & $15,8 \pm 2,05$ \\
\hline
\end{tabular}

Data tabel 1 diatas memperlihatkan kenaikan nilai histopatologi kerusakan retina. Hal ini berarti peningkatan dosis folat yang diberikan menurunkan tingkat kerusakan retina.

\section{Pembahasan}

Berdasarkan hasil penelitian diatas dapat diketahui bahwa pemberian asam folat mengurangi tingkat kerusakan retina pada keracunan metanol. Hal tersebut dilihat pada uji one way Anova yang menunjukkan nilai signifikansi 0,00 (sig. $<0,05$ ) yang berarti terdapat perbedaan nilai histopatologi kerusakan retina.

Pada uji Post hoc menunjukkan perbedaan nilai kerusakan setiap kelompok. Pada kelompok kontrol yang diberi pelet dan aquades didapatkan rata-rata nilai histopatologi kerusakan retina yang lebih tinggi dibandingkan kelompok kontrol negatif yang diberi metanol 50\% dengan dosis $7 \mathrm{~g} / \mathrm{kgBB}$, dan hasil ini bermakna secara statistik (sig. $=0,000$ ). Hasil tersebut sesuai karena pada konsumsi metanol dapat mengakibatkan kebutaan dan toksisitas pada organ visual terutama kerusakan retina akibat akumulasi asam format dalam darah $[3,9,12]$. Pada gambaran histpatologi retina yang mengalami kerusakan akan 
tampak pembengkakan fotoreseptor dan terjadi vakuolisasi sel retina (Shasriari dan Hosseini, 2000). Metanol yang diabsorpsi ke dalam tubuh akan dimetabolisme di hati oleh beberapa enzim. Enzim alkohol dehidrogenase mengoksidasi metanol menjadi formaldehyde dengan waktu paruh 1-2 menit dan enzim aldehide dehidrogenase mengoksidasi formaldehyde menjadi asam format (Seme et al, 1999). Akumulasi asam format dalam tubuh mengakibatkan gangguan fungsi mitokondria di saraf optik, yang menyebabkan hiperemi, edema dan atrofi saraf optik. Demielinisasi saraf optik terjadi akibat dari perusakan mielin oleh asam format. Kerusakan yang lebih besar terjadi pada saraf optik bagian retrolaminar, dengan pembengkakan intra-akson dan kerusakan organ dan kerusakan pada retina (Casarett et al, 1996).

Perbandingan kelompok kontrol negatif dengan kelompok perlakuan I, perlakuan II, dan perlakuan III terdapat peningkatan nilai histopatologi kerusakan retina yang bermakna secara statistik (sig. $=0,000$ ). Hasil tersebut sesuai dengan penelitian sebelumnya dimana pemberian asam folat dapat menurunkan kerusakan retina (Seme et al, 2001). Hal ini karena asam format yang terakumulasi dalam darah di metabolisme oleh asam folat menjadi karbondioksida dan air. Metabolisme oleh asam folat mengakibatkan ekskresi asam folat lebih cepat dan akumulasi di dalam tubuh tidak lama sehingga efek terhadap kerusakan retina semakin berkurang (Seme et al, 1999).

Perbandingan kelompok perlakuan I dengan kelompok perlakuan II terdapat perbedaan yang bermakna dengan nilai significancy 0,003 . Hal ini karena perbedaan dosis asam folat yang bermakna yaitu perlakuan I 1 $\mathrm{mg} / \mathrm{kgBB}$ dan perlakuan II $3 \mathrm{mg} / \mathrm{kgBB}$.

Perbandingan kelompok perlakuan I dengan kelompok perlakuan III terdapat perbedaan yang bermakna dengan nilai significancy 0,000 . Hal ini karena perbedaan dosis asam folat yang bermakna yaitu perlakuan I 1 $\mathrm{mg} / \mathrm{kgBB}$ dan perlakuan III $5 \mathrm{mg} / \mathrm{kgBB}$.

Perbandingan kelompok perlakuan II dengan kelompok perlakuan III terdapat perbedaan yang bermakna dengan nilai significancy 0,043 . Hal ini karena perbedaan dosis asam folat yang bermakna yaitu perlakuan II $3 \mathrm{mg} / \mathrm{kgBB}$ dan perlakuan III 5 $\mathrm{mg} / \mathrm{kgBB}$.

Asam folat diberikan untuk mengurangi terjadinya kerusakan akibat metabolisme metanol dalam tubuh. Asam folat bekerja dengan mempercepat oksidasi asam format menjadi karbondioksida dan air (Seme et al, 1999). Asam format merupakan hasil metabolisme metanol di hati yang mengakibatkan berbagai kerusakan sel dan dapat mengakibatkan kematian. Sesitivitas suatu spesies terhadap asam formik tergantung dari tingkat tetrahydrofolate dan 10-formylotetrahydrofolate dalam hati yang berperan pada metabolisme asam formik tersebut. Pada spesies dengan kadar folat tinggi tidak terlalu menunjukan sindrom keracunan metanol seperti pada spesies yang memiliki kadar folat dalam tubuh lebih rendah (El Bakary et al, 2006).

Terakumulasinya asam formik dalam darah dapat mengakibatkan asidosis metabolik yang berakibat fatal. Akumulasi asam formik dalam darah dapat dikurangi dengan pemberian asam folat secara intravena. Penurunan tersebut terjadi karena folat meningkatkan metabolisme asam formik menjadi karbondioksida dan air (Seme et al, 1999). Pemberian asam folat dapat memperbaiki $\mathrm{pH}$ darah akibat asidosis karena metanol, namun pada beberapa keadaan tidak terjadi perbaikan pada kerusakan mata (Moghadami dan Masoumpoor, 2002).

\section{Kesimpulan}

Berdasarkan hasil penelitian yang telah dilakukan dapat disimpulkan bahwa asam folat dapat menurunkan tingkat kerusakan retina. Pada pemberian asam folat dengan dosis $1 \mathrm{mg} / \mathrm{kgBB}, 3 \mathrm{mg} / \mathrm{kgBB}$, dan 5 $\mathrm{mg} / \mathrm{kgBB}$ secara signifikan dapat menurunkan tingkat kerusakan retina dilihat dari gambaran histopatologinya.

Namun, perlu dilakukan penelitian lebih lanjut dengan jumlah sampel yang lebih besar, waktu penelitian yang lebih lama, serta dengan dosis asam folat yang lebih luas. Penelitian lebih lanjut mengenai uji dosis efektif dan uji toksisitas pemberian 
asam folat pada penangakan keracunan metanol juga perlu dilakukan.

\section{Ucapan Terima Kasih}

Ngurah Agung mengucapkan kepada dr. Enny Suswati, M. Kes, selaku Dekan Fakultas Kedokteran Universitas Jember atas segala fasilitas dan kesempatan yang diberikan selama menempuh pendidikan di Fakultas Kedokteran Universitas Jember; dr. Al Munawir, M. Kes, Ph.D, selaku Dosen pembimbing utama dan dr. Sugiyanta, M. Ked, selaku Dosen Pembimbing Anggota yang telah meluangkan waktu, pikiran, tenaga dan perhatiannya dalam penulisan tugas akhir; dr. Muhammad Ihwan Narwanto, M. Sc, dan dr. Ali Santosa sebagai dosen penguji yang telah banyak memberikan kritik dan saran yang membangun dalam penulisan tugas akhir; semua pihak yang telah membantu terselesaikannya tugas akhir ini.

\section{Daftar Pustaka}

Acute Exposure Guidelines Levels (AEGLs) Interim 2. 2005. Methanol. CAS Reg No : 67-56-1.

Casarett, L. J., Doull, J., and Klaassen, C. D. 1996. Casarett and Doull's Toxicology: The Basic Science of Poisons. 5th ed. New York : McGraw-Hill ; 604-5, 756-7.

El-Bakary, A. A., El-Dakrory, S. A., Sohayla, M. A., Hasanein, N. A., and Malek, H. A. 2006. Retinaranitidine as an alcohol dehydrogenase inhibitor in acute methanol toxicity in rats. Journal of Toxicology and Environmental Health
Sciences. ISSN 9820. Vol. 3 (6): 145154.

Fadilla, P. P. 2010. Pengaruh Lama Pemberian Metanol 50\% Peroral Terhadap Tingkat Kerusakan Sel Gaster Tikus Wistar. Fakultas Kedokteran Universitas Diponogoro.

Moghadami, M., and Masoumpoor, M. 2002. Therapeutic response to fonilic acid in methanol poisoning epidemic in shiraz. Iran J Med Sci ; 33 (1) : 22-26.

Mulyani, S. I. 2010. "Tarif Cukai Etil Alkohol. Minuman yang Mengandung Etil Alkohol, dan Konsentrat yang Mengandung Etil Alkohol". Peraturan Menteri Keuangan Nomor 62/PMK.011/2010. Menteri Keuangan Republik Indonesia.

Pritchard, J. D. 2007. Methanol Toxicological Overview. CHAPD : HPA.

Seme, MT., Summerfelt, P., Henry, MM., Neitz, J., \& Eells, JT. 1999. Formateinduced inhibition of photoreceptor function in methanol intoxication. Pharmacol., 289(1): 361-370.

Seme, MT., Summerfelt, P., Neitz, J., Eells, JT., \& Henry, MM. 2001. Differential recovery of retinal function after mitochondrial inhibition by methanol intoxication. Investig. Ophthalmol. Vis. Sci., 42: 834-841.

Shasriari, H. A., dan Hosseini, R. A. 2000. Preventive Effects of Vitamin B12 and Folic Acid in Metanol-Induced Retinopathy in an Animal Model. Medical Journal of The Islamic Republic Of Iran. May ; 14(1) : 83-86. 